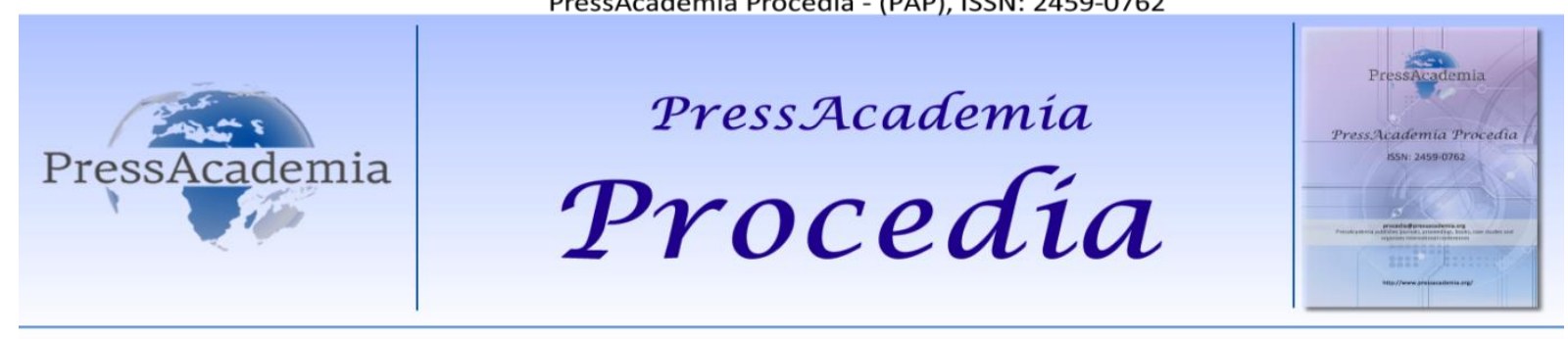

Global Business Research Congress (GBRC), May 24-25, 2017, Istanbul, Turkey

\title{
AN ANALYSIS OF THE PERCEPTIONS OF THE NURSES ABOUT THE OUTCOMES OF THE PERFORMANCE EVALUATION SYSTEM IN TERMS OF SOME OCCUPATIONAL AND DEMOGRAPHIC VARIABLES
}

DOI: 10.17261/Pressacademia.2017.650

PAP- GBRC-V.3-2017(76)-p.729-736

Abdullah Soysal ${ }^{1}$, Safak Kiran ${ }^{2}$

${ }^{1}$ Kahramanmaraş Sütçü İmam University, Department of Health Administration, Kahramanmaraş, Turkey, asoysall@ksu.edu.tr

${ }^{2}$ Kahramanmaraş Sütçü İmam University, Department of Health Administration, Kahramanmaraş, Turkey, skiran@ksu.edu.tr

\section{To cite this document}

Soysal, A. and S. Kiran, (2017). An analysis of the perceptions of the nurses about the outcomes of the performance evaluation system in terms of some occupational and demographic variables. PressAcademia Procedia (PAP), V.3, p.729-736.

Permemant link to this document: http://doi.org/10.17261/Pressacademia.2017.650

Copyright: Published by PressAcademia and limited licenced re-use rights only.

\begin{abstract}
The aim of this study is to examine the perceptions of the nurses about the outputs of the "Performance Evaluation System" applied in hospitals in terms of some occupational and demographic variables. The study was conducted by a face-to-face survey applying to 45 nurses working in a hospital to evaluate the outputs of the PDS. The data obtained from the questionnaires were tested by factor analysis and comparative statistical analyzes and the 'Cronbach's Alpha' value for scale was calculated. According to research findings, as a result of the exploratory factor analysis, it was determined that all the items on the scale were loaded in one dimension and that the factor loads were above 0.7 and the total variance explained by the one-dimensional structure was $66,855 \%$. As a result of the reliability analysis, " Cronbach's Alpha " value was calculated as 0.960 . Significant differences were found as a result of comparison of some occupational variables in terms of averages of some expressions in the scale. In conclusion, "PES" applied in hospital, it can be said that the positive perception on nurses expectations about the future can be develop and this situation can affect positively their feelings such as loyalty and belonging which can provide them to stay at work.
\end{abstract}

Keywords: Performance evaluation system, hospital, nurses, perception, loyalty and belonging

JEL Codes: I12, L25, M12

\section{HEMŞiRELERIN PERFORMANS DEĞERLENDIRME SISTEMININ ÇIKTILARINA İIŞKIN ALGILARININ BAZI MESLEKI VE DEMOGRAFIK DEĞiŞKENLER AÇISINDAN INCELENMESi}

\section{ÖZET}

Bu çalışmanın amacı, hemşirelerin hastanelerde uygulanan "Performans Değerlendirme Sistemi” nin çıktılarına ilişkin algı durumlarını bazı mesleki ve demografik değişkenler açısından incelemektir. Araştırma, bir hastanede çalışan 45 hemşireye, PDS' nin çıktılarını değerlendirmeleri amacıyla yüz yüze anket uygulanarak gerçekleştirilmiştir. Anketlerden elde edilen veriler faktör analizi ve karşılaştırmalı istatistik analizleri yoluyla test edilmiş ve ölçeğe ilişkin "Cronbach's Alpha" değeri hesaplanmıştır. Araştırma bulgularına göre, keşifsel faktör analizi sonucunda, ölçekte yer alan tüm maddelerin tek bir boyutta yüklendiği ve faktör yüklerinin 0.7 'nın üstünde olduğu ve tek boyuttan oluşan yapının açıkladığı toplam varyansın \%66,855 olduğu tespit edilmiştir. Ölçekte yer alan bazı ifadelere iliş̧in ortalamalar bakımından bazı mesleki değişkenlerin karşılaştıııması sonucunda anlamlı farklııılar bulunmuştur. Sonuç olarak, "PDS" uygulanan hastanelerde, hemşirelerin gelecekle ilgili beklentilerinde pozitif algının gelişebileceği ve bu durumun, hemşirelerin işte kalmalarını sağlayabilecek bağılık ve aidiyet gibi duygularını olumlu yönde etkileyebileceği söylenebilmektedir.

Anahtar Kelimeler: Performans değerlendirme sistemi, hastaneler, hemşireler, algı, bağ|lık ve aidiyet JEL Kodları: I12, L25, M1 


\section{GiRiş}

Günümüzde işletmelerin çoğu resmi bir performans değerlendirme sistemine sahiptir ve bu sistemde çalışanların performansları düzenli olarak ölçülmektedir. İyi bir performans değerlendirme sistemi ise işletmelere büyük avantajlar sağlar. Çalışanlara kendilerinden beklenen şeyler hakkında bilgi verir ve çalışanların örgütsel amaçlar doğrultusunda hareket etmesine yardımcı olur. Ayrıca terfi, promosyon ve işten çıkar gibi kararların alınmasının gerekip gerekmediği konusunda bilgi sağlar. Sağlık hizmetlerinde performans değerlendirme sistemleri üzerine oldukça çok sayıda araştırma bulunduğu görülmektedir. Ancak ülkemizde sisteme yönelik çalışan değerlendirmelerini odak noktasını alan oldukça az sayıda çalışma bulunmaktadır. Sistemin etkinliğini ve hakkaniyet derecesini belirlemede daha doğru sonuçlara ulaşılmasını sağlayabilecek çalışan görüşlerine dayalı araştırmaların yaygınlaşması gerektiği düşünülmektedir. Çalışan değerlendirmeleri, işletme uygulamalarındaki etkinliğin ve hakkaniyetin derecesini belirlemede önemli bir faktör olarak araştırmacılar tarafından yaygın olarak başvurulan veri kaynaklarıdır. Özellikle çalışanların doğrudan kendilerine yönelik uygulamaların sonuçlarının değerlendirilmesinde sıkça başvurulan yöntemlerden biri olarak karşımıza çıkmaktadır. Bu bağlamda bir sistemin etkinliğinin değerlendirilmesinde çalışan değerlendirmelerinin dikkate alınması gerektiği düşünülmektedir.

Hemşireler, hekim tarafından acil dışında yazılı olarak verilen tedavileri uygulamak, hastanın bakımını düzenlemek, denetlemek ve değerlendirmekle görevli ve yetkili sağlık çalışanlarıdır (TDK Sözlük, 2017). Hemşirelerin sağlık hizmeti sunumunda hastalarla uzun süre ilgilenen taraf olmaları ve diğer sağlık personellerine göre hastanelerde daha çok sayıda bulunmaları bakımından görüşlerine ayrıca önem verilmesi önerilmektedir. Bu çalışmada performans yönetimine ilişkin kavramsal çerçeveye değinilerek Türkiye'de sağlık hizmetlerinde uygulanan performans değerlendirme sistemlerinden kısaca bahsedilecektir. Çalışmanın amacı, hemşirelerin performans değerlendirme sistemine ilişkin algılarının ne yönde olduğu ve hangi faktörlerden etkilendiğini belirlemektir. Bu kapsamda Kahramanmaraş Sütçü İmam Üniversitesi Sağlık Uygulama ve Araştırma Hastanesinde çalışan hemşireler üzerine ampirik bir araştırma gerçekleştirilmiştir.

\section{LITERATÜR INCELEMESI}

Performans, belirli amaçlara yönelik planlı etkinlikler sonucu nicel ya da nitel olarak değer kazanmış kavramlardır (Eraslan ve Algün, 2004:95). Diğer bir deyişle performans, bir kişinin sahip olduğu potansiyel veya reel bilgi-maharet ve kabiliyetlerini hedeflerine veya beklentilerine ulaşabilmek için ne ölçüde kullanabildiğini tanımlayan bir kavramdır (Yıldız vd., 2008:240). Bir işletmenin performansı; stratejik, taktiksel ve operasyonel amaçlarının gerçekleştirilmesinde, çalışanların işin nitelik ve gereklerini yerine getirmek için gösterdikleri tüm çabaların değerlendirilmesi olarak tanımlanabilir. Değerlendirme, ölçme sonuçlarını belirli bir ölçüt sistemine dayanarak, ölçülen nitelik hakkında bir değer yargısına varma süreci olarak tanımlanabilir (Eraslan ve Algün, 2004:95). Performans değerlendirme, bir yöneticinin önceden saptanmış standartlarla karşılaştırma ve ölçme yoluyla personelin işteki performansının değerlendirilmesi süreci ya da bireyin görevindeki başarısı, işteki tutumu ve davranışları, ahlaki durumu ve özelliklerini ayrıntılayan ve bütünleyen, kısaca bireyin kuruluşun başarısına olan katkılarını değerlendiren planlı bir araçtır (Eraslan ve Algün, 2004:95). Ayrıca, kişinin, özellik ve yeteneklerine uygun olan işi, kabul edilebilir sınırlar içinde yerine getirmesi olarak tanımlanmaktadır (Yıldız vd., 2008:240).

Performans değerlendirme sistemlerine ilişkin yapılan birçok çalışma, organizasyonlarda insan kaynakları yönetiminin başarılı olabilmesi için, etkili bir Performans Değerlendirme Sisteminin (PDS) kurulup işletilmesine ihtiyaç olduğunu göstermektedir. Organizasyonların başarılı bir şekilde faaliyetlerine devam edebilmesi için kritik bir öneme sahip olmasından dolayı, performans yönetimi ve performans yönetiminin bir alt konusu olan performans değerlendirme, insan kaynakları yönetiminde en çok araştırılan konuların başında gelmektedir (Mert, 2011:88). Performans yönetimi, birçok ülkede gerek merkezi hükümet düzeyinde gerekse yerel yönetimlerde popülerlik kazanan piyasa temelli kamu yönetimi reformlarının başında gelen yaklaşımlardan biridir. Performans ölçümü, performansa dayalı ücret ve performans denetimi gibi birbirine bağlı bileşenlerin oluşturduğu performans yönetimi uygulamalarının, çalışanların kurumsal bağlılığını da güçlendirdiği varsayılarak kamu kurumlarında bürokrasiden kaynaklanan olumsuzlukları gidermek ve yönetsel kapasiteyi güçlendirmek amacıyla bu yönetim tekniğine başvurulmaktadır (Ateş ve Kırılmaz, 2015:99).

Günümüzün rekabetçi ortamında kamu kuruluşlarını da kapsayan birçok örgüt, performans değerlendirmeyi, nitelikli çalışanları örgüte çekmek, iş doyumu ile verimi artırmak için stratejik bir araç olarak kullanmakta, değerlemeyi birçok yönetsel karara temel olarak almaktadır. Performans değerlendirme aynı zamanda, çalışanın performansının yönetimi ve geliştirilmesinde, zamanında ve doğru kadrolama kararlarında ve mal ve hizmetin bütününün kalitesinin geliştirilmesinde gittikçe artan öneme sahip bir insan kaynakları uygulaması haline de dönüşmüştür (Bakan ve Kelleroğlu, 2003:104). Performans değerlendirmenin artan önemi pek çok örgüt gibi sağlık hizmeti sunan örgütler açısından da göz önünde bulundurulması gereken bir unsur olarak değerlendirilebilmektedir. Ancak sağılı kurumlarında performans değerlendirme, üretilen hizmetin tanımlanmasındaki zorluklar, üretildiği anda tüketildiği için miktarını belirlemedeki zorluklar, kaynak tahsisinin güç olması ve hizmet sunum koşullarının homojen olmaması gibi nedenlerden dolayı net bir şekilde uygulanamamaktadır (Fettah ve Şahin, 2009:179). Buna karşılık sağlık sisteminde var olan sorunların azaltılması, çalışanların verimliliğinin ve performansının artırıması ve kaliteli ve verimli hizmet sunumunun teşvik edilmesi için performans değerlendirme sistemi sağlık kurumları açısından etkin bir insan kaynakları uygulaması haline gelmiştir (Sağlık Bakanlığı, 
2006). Günümüzde sağlık sektörü kamu harcamalarında en büyük payı alan sektörlerden birisidir. Bu nedenle gerek sağlık hizmetlerine ayrılan kaynakların tahsisinde, gerekse sunulan hizmetin kalitesi hakkında karar alıcılara önemli bir gösterge olması nedeniyle sağlık kurumlarında performans değerlendirmesi büyük önem arz etmektedir (Tengilimoğlu ve Toygar, 2013:50). Performans değerlendirme sistemlerinin uygulanması sonucunda oluşan performans göstergeleri ayrıca, sağlık alanında gelişmeleri resmi olarak belgelemek isteyen ülkeler ve sağlık sisteminin geliştirilmesi ve reformuna ilişkin kanıt toplayan araştırmacılar için önemli bir ölçüt olarak değerlendirilebilmektedir (Kruk ve Freedman, 2008:265).

\subsection{Türkiye Sağlık Sistemi Performans Yönetimi}

Türkiye'de Performans Yönetimi Modeline ilk olarak performansa dayalı ücret sistemiyle 2003 yılında 10 pilot hastanede uygulamaya koyularak geçilmiştir. Bu sistem Sağlıkta Dönüşüm Programı kapsamında 2004 yılında Sağlık Bakanlığı'na bağlı tüm kurum ve kuruluşlarda uygulanmaya başlamıştır. Ancak sistem niceliği ön planda tuttuğu ve kaliteyi geri plana ittiği dolayısıyla yoğun eleştirilere maruz kalmıştır. Bu nedenle 2005 yılında yürürlüğe giren "Sağlık Bakanlığı Yataklı Tedavi Kurumları Kurumsal Kaliteyi Geliştirme ve Performans Değerlendirme Yönergesi" ile Performans Yönetimi Modeli içine bireysel performans yönetim sisteminin yanı sıra kurumsal performans yönetimi de dahil edilmiştir (Kırılmaz vd., 2014:336).

Türkiye'de sağlık hizmeti performans değerlendirmeleri il bazında II Sağlık Müdürlüğü’ne Bağlı İ Performans ve Kalite Koordinatörlüğü ve hastanelerde Performans ve Kalite birimleri aracılığı ile yürütülmektedir. Ayrıca Bakanlığa bağlı bağımsız birimler tarafından da denetim yapılabilmektedir. (Tengilimoğlu ve Kocakoç, 2014:18). Performans değerleme sistemini "Kurumsal Performans Ölçümü ve Kalite Geliştirme Uygulaması" ve "Performansa Dayalı Ek Ödeme Sistemi" olarak iki ana başlık altında incelemek mümkündür. Kurumsal performans ölçümleri 12/05/2006 tarihli ve 26166 sayılı Resmi Gazete'de yayımlanarak 01.04.2006 tarihinden itibaren yürürlüğe giren "Sağlık Bakanlığına Bağlı Sağlık Kurum ve Kuruluşlarında Kaliteyi Geliştirme ve Performans Değerlendirme Yönergesi" uyarınca yürütülmektedir (Sağlık Bakanlığı, 2006). Yönergeye göre kurumsal performans "Hastanelerde", "ADSM" lerde" ve "1. Basamak Sağlık Kuruluşları' nda" "Muayeneye Erişim", "Hizmet Kalitesi", "Memnuniyet Ölçümleri" ve "Verimlilik Göstergeleri" gibi kriterlere göre çeşitli katsayıların belirlenerek ölçme ve değerlendirme yapıldığı bir sistem olarak tasarlanmıştır.

"Performansa Dayalı Ek Ödeme Sistemi” kamu ve üniversite hastanelerinde genel olarak personele dağıtılan primler olarak karşımıza çıkmaktadır. Bu sistem, çok çalışarak iyi iş yapan personelin ödüllendirilmesi, çalışanların motive edilmesi, cezbedilerek çalışanların daha uzun süre kurumda kalmalarının sağlanması ve bu sayede hizmet kalitesi ve verimliliğin artııımasını gibi amaçları kapsaması bakımından çalışan odaklı bir yaklaşım olarak değerlendirilebilmektedir. Bu amaçla, personelin katkısıyla elde edilen döner sermaye gelirlerinden, kapsamda yer alan personele, personelin unvanı, görevi, çalışma şartları ve süresi, hizmete katkısı, performansı, serbest çalışıp çalışmaması ile muayene, ameliyat, anestezi, girişimsel işlemler ve özellik arz eden riskli bölümlerde çalışma gibi unsurlar esas alınarak ek ödeme yapılabilmektedir (Erkan, 2011:425).

\subsection{P.D.S' ye İlişkin Literatürdeki Çalışma Bulguları}

Sosyo-demografik özelliklerin performans ve performans değerlendirme sistemi ile ne tür bir ilişkisi olabileceğini belirleyebilmek adına farklı alanlarda yapılan çalışma bulgularına ve sonuçlarına ulaşılış̧tır.

Ateş ve Kırılmaz (2015) yaptıkları çalışmada, sağlık personelinin performans yönetimine ilişkin görüşleri üzerinde kişisel faktörlerin etkisini incelemek amacıyla Sağlık Bakanlığı'na bağlı 6 hastanede farklı unvanlarda sağlık çalışanına anket uygulamışlardır. Araştırma sonuçları bu çalışma doğrultusunda incelendiğinde çalışanların performans değerlendirme sistemine ilişkin görüşleri, kadroya ilişkin statüleri ve eğitim durumu bakımından anlamlı farklılık göstermiştir (Ateş ve Kırılmaz, 2015:109). Mert (2011) yaptığı bir çalışmada, çalışanların performans değerlendirme sisteminin çıktı ve engellerine ilişkin algıyı ölçmek üzere, savunma sanayi organizasyonunda bulunan ve yönetici ve çalışanlardan oluşan bir gruba anket uygulamıştır. Çalışma sonucunda çalışanların performans değerlendirme sistemine ilişkin algılarının cinsiyete göre farklılaştığı sonucuna ulaşmıştır (Mert, 2011:100). Mohamed Shaffril ve Uli (2010) yaptıkları çalışmada, Malezya' da hükümet tarım ajansı çalışanlarının sosyo-demografik özelliklerinin iş performansı üzerine etkilerini incelemiştir. Araştırma sonuçlarına göre çalışanların iş deneyimlerinin iş performansı üzerine olumlu ancak düşük bir etkisi olduğu sonucuna ulaşmışlardır (Mohamed Shaffril ve Uli, 2010:467).

Hassan ve Ogunkoya (2014) yaptıkları çalışmada, Nijerya sigorta endüstrisindeki sigorta satış danışmanlarının demografik özellikleri ile iş performansları arasındaki ilişkiyi incelemiştir. Araştırma sonucunda iş performansı ile çalışanların medeni durumları arasında anlamlı bir ilişki olduğu sonucuna varmışlardır. Bu durumu evli insanların iş/yaşam dengesini kurmakta harcadıkları çabaların iş performansını olumsuz etkileyebileceği ile açıklamışlardır (Hassan ve Ogunkoya, 2014:28). Xavier (2015) Hindistan' da üretim firmalarında çalışan personele yönelik yaptığı çalışmada, performans değerlendirme sistemlerinin etkililiğini ve çalışanların sosyo-demografik özellikleri ile birlikte etkisini incelemiştir. Araştırma sonucunda çalışanların yaşları ile genel performans değerlendirme sistemi arasında bir ilişkinin olduğu sonucuna ulaşmıştır (Xavier, 2015:29).

Bu çalışmalardaki bulgular ve sonuçlar ışığında araştırmaya ilişkin hipotezler aşağıdaki gibi kurulmuştur. 
H1: Performans değerlendirme sisteminin çıktılarına yönelik algı çalışılan birime göre anlamlı farklııı göstermektedir.

H2: Performans değerlendirme sisteminin çıktılarına yönelik algı yaşa göre anlamlı farklılık göstermektedir.

H3: Performans değerlendirme sisteminin çıktılarına yönelik algı cinsiyete göre anlamlı farklılık göstermektedir.

H4: Performans değerlendirme sisteminin çıktılarına yönelik algı eğitim durumuna göre anlamlı farklılık göstermektedir.

H5: Performans değerlendirme sisteminin çıktılarına yönelik algı medeni duruma göre anlamlı farklılık göstermektedir.

H6: Performans değerlendirme sisteminin çıktılarına yönelik algı deneyime göre anlamlı farklılık göstermektedir.

H7: Performans değerlendirme sisteminin çıktılarına yönelik algı çalışma statüsüne göre anlamlı farklıık göstermektedir.

H8: Performans değerlendirme sisteminin çıktılarına yönelik algı çalışma şekline göre anlamlı farklılık göstermektedir.

H9: Performans değerlendirme sisteminin çıktılarına yönelik algı haftalık çalışma saatine göre anlamlı farklılık göstermektedir.

\section{VERI VE YÖNTEM}

Bu çalışmada, hemşirelerin performans değerlendirme sistemine ilişkin algıları bazı mesleki ve sosyo-demografik değişkenler açısından incelenecektir. Çalışma evrenini Kahramanmaraş Sütçü İmam Üniversitesi Sağlık Uygulama ve Araştırma Hastanesinde görev yapan hemşireler oluşturmaktadır. Veri elde etmek için 45 hemşireye yüz yüze anket uygulanmıştır. Anketin ilk kısımda, Mert (2011) tarafından yapılan çalışmada performans değerlendirme sisteminin çıktılarına ilişkin algıyı incelemek üzere kullanılan 14 maddelik ölçekten faydalanılmıştır. Ölçekte yer alan ifadeler beşli likert sistemine göre derecelendirilmiştir (1-Kesinlikle katılmıyorum ........ 5-Kesinlikle katılıyorum). İkinci kısımda ise katılımcıların sosyodemografik ve mesleki özelliklerinin yer aldığı 9 maddelik anket formu kullanılmıştır. Elde edilen veriler SPSS (Statistical Package for The Social Sciences) Version 22 analiz programı kullanılarak karşılaştırmalı istatistik yöntemleriyle analiz edilmiştir. Araştırmada kullanılan ölçeğin yapı geçerliliği keşifsel faktör analizi ile test edilmiştir. Ölçeğin güvenirliği ise maddelerin içsel tutarılıı̆ını gösteren Cronbach's Alpha katsayısı ile incelenmiştir. Keşifsel faktör analizinde, temel bileşenler yöntemi ve varimax eksen dönüştürmesi teknikleri kullanılmıştır. Kaiser-Meyer-Olkin (KMO) ve Bartlett testler, ölçeğin faktör analizine uygunluğu, örneklem büyüklüğünün yeterliliği ve verilerin normal dağılımda olup olmadığını saptamak maksadıyla yapılmıştır.

\section{BULGULAR VE TARTIŞMA}

Temel demografik verilere göre katılımcıların \%57,8' i kadınlardan \%42,2' si erkeklerden oluşmaktadır. Yaş durumuna göre 25 yaş ve altı grupla 26-35 yaş aralığındaki katılımcı sayılarının eşit olduğu ve toplamın \%97,8'ini oluşturduğu görülmektedir. Katılımcıların eğitim durumuna ilişkin bilgilere göre $\% 55,6^{\prime}$ sı lisans, $\% 33,3^{\prime}$ ü sağlık meslek lisesi, \%8,9'u ön lisans ve $\% 2,2^{\prime}$ lik kısmı ise lisansüstü eğitim seviyesine sahiptir. Katılımcıların medeni durumuna ilişkin bilgilerine bakıldığında \%62,2'sinin evli ve $\% 37,8^{\prime}$ inin bekar olduğu görülmektedir.

Tablo 1: Katılımcıların Sosyo-Demografik Özelliklerine ilişkin Bulgular

\begin{tabular}{|c|c|c|c|c|c|}
\hline Cinsiyet & $\mathbf{N}$ & $\%$ & Birim & $\mathbf{N}$ & $\%$ \\
\hline Erkek & 19 & 42,2 & Cerrahi Birimler & 4 & 8,8 \\
\hline Kadın & 26 & 57,8 & Dahili Birimler & 16 & 35,6 \\
\hline Yaş & $\mathbf{N}$ & $\%$ & Yoğun Bakım & 25 & 55,6 \\
\hline 25 yaş ve altı & 22 & 48,9 & Eğitim Düzeyi & $\mathbf{N}$ & $\%$ \\
\hline $26-35$ yaş & 22 & 48,9 & SML & 15 & 33,3 \\
\hline 36 ve üzeri & 1 & 2,2 & Ön lisans & 4 & 8,9 \\
\hline Medeni durum & $\mathbf{N}$ & $\%$ & Lisan & 25 & 55,6 \\
\hline Evli & 17 & 37,8 & Lisansüstü & 1 & 2,2 \\
\hline Bekar & 28 & 62,2 & Çalışma Statüsü & $\mathbf{N}$ & $\%$ \\
\hline Deneyim & $\mathbf{N}$ & $\%$ & Kadrolu & 11 & 24,4 \\
\hline $1-5 \mathrm{yıl}$ & 36 & 80,0 & Sözleşmeli & 21 & 46,7 \\
\hline 6-10 yıl & 8 & 17,8 & Şirket Personeli & 13 & 28,9 \\
\hline 11-15 yıl & 1 & 2,2 & Çalışma Şekli & $\mathbf{N}$ & $\%$ \\
\hline Haftalık Çalışma Saati & $\mathbf{N}$ & $\%$ & Sürekli gündüz & 11 & 24,4 \\
\hline 40 saat altı & 3 & 6,6 & Bazen gündüz bazen gece & 32 & 71,2 \\
\hline $40-50$ saat & 30 & 66,7 & Sürekli gece & 2 & 4,4 \\
\hline 50 saat üzeri & 12 & 26,7 & & & \\
\hline
\end{tabular}


Tablo 2'de Keşifsel faktör analizi sonucunda, tüm maddelerin tek bir boyutta yüklendiği ve faktör yüklerinin 0.7'nın üstünde olduğu ve tek boyuttan oluşan yapının açıkladığı toplam varyansın \%66,855 olduğu tespit edilmiştir. Yapılan güvenirlik analizi sonucunda ise, ölçeğin Cronbach Alpha değeri 0.960 olarak hesaplanmıştır. Ölçeğin faktör analizine uygunluğunun ölçülmesi için Kaiser-Meyer-Olkin ve Bartlett ölçümlerine bakılmıştır. Bartlett sınaması değeri değişkenlerin birbiriyle ilişkili olup olmadığını gösteren bir ölçümdür. Bu değer p=0,000 anlamlılık düzeyinde 707,319 olarak hesaplanmıştır. Kaiser-MeyerOlkin testi ile örneklem büyüklüğünün yeterliliğini test etmek amaçlanmıştır. Ölçüm sonunda KMO değeri ,894 olarak hesaplanmıştır. Sosyal bilimler alanında bu değerin ,60' dan büyük olması örneklemin yeterli büyüklükte olduğunu göstermektedir (Bilge ve Bal, 2012:140).

Tablo 2: PDS Çıktıları Ölçeğinin Faktör Analiz Sonuçları ve Faktör Yükleri, Ortalamalar ve Standart Sapmalar

\begin{tabular}{llll}
\hline Performans değerlendirme; & Faktör Yükü & Ortalama & $\begin{array}{l}\text { Standart } \\
\text { Sapma }\end{array}$ \\
\hline $\begin{array}{l}\text { Çalışanların, yöneticilerin onlardan beklentilerini öğrenmelerini } \\
\text { sağlar. }\end{array}$ & \multirow{2}{*}{, 708} & \multirow{2}{*}{3,137} \\
\hline Kurumun ilerlemesine katkıda bulunur. &, 822 & 3,867 & 1,100 \\
\hline Eğitime yönelik stratejilerin geliştirilmesini sağlar. &, 879 & 3,844 & 1,021 \\
\hline Çalışanların kendileri hakkında bir şeyler öğrenmelerini sağlar. &, 813 & 3,867 &, 990 \\
\hline Geleceğe yönelik planların geliştirilmesini sağlar. &, 770 & 3,867 & 1,035 \\
\hline Performans ve ödül arasında bir ilişki oluşturur. &, 873 & 3,932 & 1,194 \\
\hline Çalışanların performans ve hedeflerini birleştirir. &, 899 & 3,932 & 1,095 \\
\hline Çalışanların performansını arttırır. &, 893 & 4,000 & 1,128 \\
\hline $\begin{array}{l}\text { Değerlendirme sonuçlarını performansı geliştirici bir geri bildirime } \\
\text { dönüştürür. }\end{array}$ &, 865 & 3,886 &, 982 \\
\hline Çalışanlara nasıl çalıştıklarına yönelik bilgi verir. &, 709 & 4,023 &, 965 \\
\hline Motivasyonu yükseltir. &, 827 & 1,095 \\
\hline Çalışanlar arasında eşitlik duygusu oluşturur. &, 810 & 4,067 & 1,106 \\
\hline Çalışanların işte kalma (kurumda çalışma) süresini uzatır. &, 745 & 3,956 & 1,104 \\
\hline Çalışanların stresini azaltır. &, 801 & 3,911 & 1,384 \\
\hline
\end{tabular}

Cronbach Alpha: ,960

Toplam Açıklanan Varyans Oranı: $\% 66,855$

KMO: ,894

Bartlett Düzeyi: 707,319, $p=0,000$

Tablo 3'e göre çalışanların PDS' nin çıktılarına ilişkin algı ortalamaları cinsiyete ve medeni duruma göre farklılık $(p=0,156>p=0,05)$ ve $(p=0,683>p=0,05)$ göstermemiştir. Bu durumda H3 ve H5 hipotezleri reddedilmiştir.

Tablo 3: PDS’ nin Çıktılarına Yönelik Algı Ortalamalarının Cinsiyete ve Medeni Duruma Göre Farklılığının Testine illişkin T Testi Sonuçları

\begin{tabular}{|c|c|c|c|c|c|}
\hline & & Mean & S.D. & $\mathrm{F}$ & $P$ \\
\hline \multirow{2}{*}{ Cinsiyet } & Erkek & 3,6613 & ,96844 & \multirow{2}{*}{1,518} & \multirow[b]{2}{*}{ 156, } \\
\hline & Kadın & 4,0463 & 81672 & & \\
\hline \multirow{2}{*}{ Medeni Durum } & Evli & 3,9741 & ,88560 & \multirow[b]{2}{*}{ 412 } & \multirow{2}{*}{683} \\
\hline & Bekar & 3,8570 & 92851 & & \\
\hline
\end{tabular}

Tablo 4'te PDS' nin çıktılarına ilişkin algının çalışılan birime göre farklılaşıp farklılaşmadığını ölçmek üzere Tek Yönlü Varyans analizi yapılmış, $p=0,05$ anlamlılık düzeyinde anlamlı bir fark ( $p=0,099, p>0,05)$ olmadığı sonucuna ulaşılmış ve $\mathrm{H} 1$ hipotezi reddedilmiştir. Buna karşın, Tablo 5'e göre ölçekte yer alan "PDS Çalışanların İşte Kalma Süresini Uzatır" ifadesine verilen yanıtların ortalaması çalışılan birime göre anlamlı farklılık $(p=0,004<p=0,05)$ göstermiştir. Ifadeye ilişkin ortalamalar karşılaştırıldığında "yoğun bakım" çalışanlarının en yüksek ortalamaya $(=4,1200)$ sahip olduğu sonucuna ulaşılmıştır.

Tablo 4: PDS’nin Çıktılarına İlişkin Algının Çalışılan Birime Göre Farklılaşıp Farklılaşmadığının Testine ilişkin ANOVA Sonuçları

\begin{tabular}{llllll}
\hline & & Mean & S.D. & F. & P \\
\hline \multirow{3}{*}{ Çalışılan Birim } & Cerrahi Birimler & 2,9821 &, 46793 & & \multirow{2}{*}{2,439} \\
\cline { 2 - 4 } & Dahili Birimler & 4,0312 &, 82601 & \multirow{2}{*}{, 999} \\
\cline { 2 - 4 } & Yoğun Bakım & 3,9336 &, 92718 & & \\
\hline
\end{tabular}


Tablo 5: "PDS Çalışanların İşte Kalma Süresini Uzatır" ífadesine Verilen Yanıtların Ortalamalarının Çalışılan Birime Göre Farklılaşıp Farklılaşmadığının Testine İlişkin ANOVA Sonuçları

\begin{tabular}{|c|c|c|c|c|c|}
\hline & & Mean & S.D. & $F$ & $P$ \\
\hline \multirow{3}{*}{ Çalışılan Birim } & Cerrahi Birimler & 2,2500 & ,95743 & \multirow{3}{*}{6,218} & \multirow{3}{*}{0,004} \\
\hline & Dahili Birimler & 4,0000 & 1,09545 & & \\
\hline & Yoğun Bakım & 4,1200 & ,92736 & & \\
\hline
\end{tabular}

Tablo 6'da PDS' nin çıktılarına ilişkin algının çalışma statüsüne göre farklılaşıp farklılaşmadığını ölçmek üzere Tek Yönlü Varyans analizi yapılmış, $p=0,05$ anlamlılık düzeyinde anlamlı bir farklılık $(p=0,577>p=0,05)$ olmadığı sonucuna ulaşılmış ve H7 hipotezi reddedilmiştir. Buna karşın, Tablo 7'ye göre ölçekte yer alan "PDS Geleceğe Yönelik Planların Geliştirilmesini Sağlar" ifadesine verilen yanıtların ortalaması çalışma statüsüne göre anlamlı bir farklılık $(p=0,047<p=0,05)$ göstermiştir. Ifadeye ilişkin ortalamalar karşılaştırıldığında "Kadrolu (657' li)" çalışanların en yüksek ortalamaya $(=4,4545)$ sahip olduğu sonucuna ulaşılmıştır.

Tablo 6: PDS’ nin Çıktılarına ilişskin Algının Çalışma Statüsüne Göre Farklılaşıp Farklılaşmadığının Testine ỉlişkin ANOVA Sonuçları

\begin{tabular}{llllll}
\hline & & Mean & S.D. & F & P \\
\hline \multirow{3}{*}{ Çalışma Statüsü } & Kadrolu (657'li) & 4,1035 &, 82148 & & \\
\cline { 2 - 4 } & Sözleşmeli & 3,7512 &, 95496 & \multirow{2}{*}{, 577} \\
\cline { 2 - 4 } & Şirket Personeli & 3,9121 &, 87974 & \\
\end{tabular}

Tablo 7: "PDS Geleceğe Yönelik Planların Geliştirilmesini Sağlar" ifadesine Verilen Yanıtların Ortalamalarının Çalışma Statüsüne Göre Farklılaşıp Farklılaşmadığının Testine ilişkin ANOVA Sonuçları

\begin{tabular}{llllll}
\hline & & Mean & S.D. & F & P \\
\hline \multirow{3}{*}{ Çalışma Statüsü } & Kadrolu (657'li) & 4,4545 &, 82020 & & \\
\cline { 2 - 4 } & Sözleşmeli & 3,5000 & 1,19208 & \multirow{2}{*}{0,047} \\
\cline { 2 - 4 } & Şirket Personeli & 3,9231 &, 75955 & \\
\hline
\end{tabular}

Tablo 8'e göre araştırmanın diğer hipotezlerine ilişkin yapılan Tek Yönlü Varyans Analizi sonuçlarında herhangi bir anlamlı farklılık bulunamamış ve H2, H4, H6, H8 ve H9 hipotezleri de reddedilmiştir. Bu durum Tablo 8'de gösterilmiştir.

Tablo 8: PDS' nin Çıktılarına İlişkin Algının Yaşa, Eğitim Durumuna, Deneyime, Çalışma Şekline ve Haftalık Çalışma Saatine Göre Farklılaşıp Farklılaşmadığının Testine İlişkin ANOVA Sonuçları

\begin{tabular}{|c|c|c|c|c|c|}
\hline & & Mean & S.D. & $\mathrm{F}$ & $\mathrm{P}$ \\
\hline \multirow{4}{*}{ Eğitim Durumu } & SML & 3,7378 & ,88136 & \multirow{4}{*}{,789 } & \multirow{4}{*}{,507 } \\
\hline & Önlisan & 3,6607 & 60994 & & \\
\hline & Lisans & 3,9624 & ,94151 & & \\
\hline & Lisansüstü & 5,0000 & . & & \\
\hline \multirow{3}{*}{ Yaş } & 25 ve altı & 3,7790 & ,92189 & \multirow{3}{*}{1,132} & \multirow{3}{*}{,332 } \\
\hline & $26-35$ yaş & 4,0352 & 86017 & & \\
\hline & $36-45$ yaş & 2,8571 & . & & \\
\hline \multirow{3}{*}{ Deneyim } & $1-5 \mathrm{yll}$ & 3,8211 & ,92021 & \multirow{3}{*}{1,635} & \multirow{3}{*}{ 207 } \\
\hline & 6-10 yıl & 4,2940 & ,65530 & & \\
\hline & $11-15$ yıl & 2,8571 & . & & \\
\hline \multirow{3}{*}{ Çalışma Şekli } & Gündüz & 3,6818 & ,85676 & \multirow{3}{*}{,722 } & \multirow{3}{*}{,492 } \\
\hline & Gündüz ve Gece & 3,9816 & 83736 & & \\
\hline & Gece & 3,4286 & 2,22234 & & \\
\hline \multirow{3}{*}{ Çalışma Saati } & 40 altı & 3,8095 & ,73309 & \multirow{3}{*}{ 122 } & \multirow{3}{*}{,886 } \\
\hline & $40-50$ saat & 3,8471 & ,92837 & & \\
\hline & 50 üzeri & 3,9940 & ,90014 & & \\
\hline
\end{tabular}




\section{SONUÇ}

Çalışanların ölçekte yer alan "PDS Çalışanların İşte Kalma Süresini Uzatır" ifadesine verilen yanıtların ortalaması çalışılan birime göre anlamlı farklılık göstermiştir. Iffadeye ilişkin ortalamalar karşılaştırıldığında ise "yoğun bakım" çalışanlarının en yüksek ortalamaya $(=4,1200)$ sahip olduğu sonucuna ulaşılmıştır. Yoğun bakım üniteleri teknik olarak kompleks tedavilerin uygulandığı ve sürekli hasta takibinin yapıldığı uzmanlaşmış birimlerdir (Çelen vd., 2007:26). Çoğunlukla terminal dönemde bulunan ve de yoğun stres altında bulunan hasta ve yakınlarına hizmet vermektedir. Bundan dolayı yoğun bakım hemşirelerinin her an acil hasta kabulü, acil tedavi ve bakım girişimlerine hazır olması gerektiği için oldukça stresli bir ortama sahiptir (Sabuncu vd.,1999:11). Özellikle yoğun bakım hemşireleri diğer sağlık çalışanlarına göre geniş bir zaman dilimi içinde şiddetli ağrı çeken hastalarla ve ölümlerle sık karşılaşmakta ve ağır hastalıkları olan hastalara ve yakınlarına hizmet vermektedir (Kahraman vd., 2011:12). Bu şartlar göz önüne alındığında diğer çalışanlara kıyasla daha fazla takdir edilmeye ihtiyaç duyabilecekleri söylenebilir. Bu bakımdan performanslarının ölçülmesi ve aynı oranda ödüllendirilmesi motivasyonlarına ve işe bağlılıklarına dolayısıyla işte kalma sürelerine olumlu etki edebilecektir.

Çalışanların ölçekte yer alan "PDS Geleceğe Yönelik Planların Geliştirilmesini Sağlar" ifadesine verilen yanıtların ortalaması çalışma statüsüne göre anlamlı farklılık göstermiştir. İadeye verilen yanıtlara ilişkin ortalamalar karşılaştırıldığında "Kadrolu (657' li)" çalışanların en yüksek ortalamaya $(=4,4545)$ sahip olduğu sonucuna ulaşıımıştır. Bu sonuca göre iş garantisi daha yüksek olan sağlık çalışanlarının daha yüksek oranda gelecek odaklı düşünebildiklerini söylemek mümkündür. Gelecek odaklı düşünce tarzı hem kurumun hem de çalışanın gelişimini olumlu yönde etkileyici bir unsur olarak değerlendirilmektedir. Ayrıca kurumsal aidiyet düzeyi daha yüksek olduğu düşünülen kadrolu çalışanların PDS ile kurumsal gelişime de önem verdiği düşünülmektedir. Bu kapsamda PDS'nin diğer çalışma statüsüne göre çalışanlarla kadrolu çalışanlar arasındaki farkı dengeleyebilecek yöntemleri sunabileceği değerlendirilmektedir. Bu sayede her çalışan için kurumun geleceğine önem veren bir algının geliştirilebileceği düşünülmektedir. Çalışanların PDS’ nin çıktılarına ilişkin algıları mesleki ve sosyodemografik özelliklerine göre anlamlı farklılık göstermemiştir. Bu sonucun katılımcı sayısındaki azlıktan kaynaklandığı düşünülmektedir. Daha fazla sayıda katılımcıya ulaşılamaması katılımcıların performans ödemesi almadıklarını belirtmeleri ve bu yüzden anketi cevaplamayacaklarını bildirmelerinden kaynaklanmaktadır. Bu durum araştırmanın bir sınırlılığı olarak değerlendirilmiştir. Illeride yapılacak çalışmalar için benzer çalışmanın daha fazla katılımcıya erişilerek yapılması önerilmektedir. Bu sayede Performans Değerlendirme Sistemlerine yönelik geliştirme ve düzenleme faaliyetlerinde daha doğru kararların alınabileceği öngörülmektedir.

Sağlık kurumlarında performans değerlendirme sistemi genelde çalışanların ek kazanç sağladığı bir sistem olarak düşünülmektedir. Bu düşünceden yola çıkarak sağlık hizmetlerinde adil bir performans değerlendirme sisteminin olması ve bunun finansal olarak da sağ ık çalışanlarına yansıması durumunda çalışanların kurumsal aidiyet ve işe devamlılıklarının sağlanmasında olumlu gelişmeler yaşanabileceği düşünülmektedir. Bu bağlamda sağlık kurumlarında performans değerlendirme sistemlerinin ve buna bağlı ek ücret uygulamalarının gerekliliği önemli bir husus olarak değerlendirilmektedir.

\section{KAYNAKLAR}

Ateş, H., Kırılmaz, H. (2015). Sağlık Personelinin Performans Yönetimine İlişkin Görüşleri Üzerinde Kişisel Faktörlerin Etkileri. Amme İdaresi Dergisi, vol.48, no.4, p. 97-128.

Bakan, İ., Kelleroğlu, H. (2003). Performans Değerlendirme: Çalışanların Performans Değerlendirme Uygulamalarından Beklentileri Konusunda Bir Alan Çalışması. Süleyman Demirel Üniversitesi i.i..B.F Dergisi, vol.8, no.1, p. 103-127.

Bilge, H., Bal, V. (2012). Girişimcilik Eğilimi: Celal Bayar Üniversitesi Öğrencileri Üzerine Bir Araştırma. Süleyman Demirel Üniversitesi Sosyal Bilimler Enstitüsü Dergisi, vol.16, no.2, p. 131-148.

Çelen, Ö., Karaalp, T., Kaya, S., Demir, C., Teke, A., Akdeniz, A. (2007). Gülhane Askeri Tıp Fakültesi Eğitim Hastanesi Yoğun Bakım Ünitelerinde Görev Yapan Hemşirelerin Uygulanan Hizmet İçi Eğitim Programlarından Beklentileri Ve Bu Programlar ille İlgili Düşünceleri. Gülhane Tıp Dergisi, vol.49, no.1, p.25-31.

Eraslan, E., Algün, O. (2005). İdeal Performans Değerlendirme Formu Tasarımında Analitik Hiyerarşi Yöntemi Yaklaşımı. Gazi Üniversitesi Mühendislik ve Mimarlık Fakültesi Dergisi, vol.20, no.1, p. 95-106.

Erkan, A. (2011). Performansa Dayalı̈ Ödeme: Sağlık Bakanlığı Uygulaması. Maliye Dergisi, no.160, p.423-438.

Fettah, K., Şahin, B. (2009). Birinci Basamak Sağlık Kuruluşlarında Çalışan Personelin Performansa Dayalı Döner Sermaye Ek Ödeme Uygulamasına İlişskin Değerlendirmeleri. Hacettepe Sağlık İdaresi Dergisi, vol.12, no.2, p. 177-201.

Hassan, B., Ogunkoya, O. (2014). Demographic Variables and Job Performance: Any Link? Acta Universitatus Danubius Economica, vol.10, no.4, p. 19-30.

Kahraman, G., Engin, E., Dülgerler, Ş., Öztürk, E. (2011). Yoğun Bakım Hemşirelerinin İş Doyumları Ve Etkileyen Faktörler. Dokuz Eylül Üniversitesi Hemşirelik Yüksekokulu Elektronik Dergisi, vol.4, no.1, p.12-18 
Karasar, N. (2014). Bilimsel Araştırma Yöntemi (27. Bs.), Nobel Yayınevi, Ankara.

Kırılmaz, H., Akbolat, M., Ayparçası, F. (2014). Performans, Kalite ve Hasta Güvenliği Konulu Sağlık Haberleri Üzerine Bir İçerik Analizi. Uluslararası Hakemli İletişim ve Edebiyat Araştırmaları Dergisi, vol.2, no.5, p.329-350.

Kruk, E. M., P. L. Freedman (2008). Assessing Health System Performance in Developing Countries: A Review of The Literatur. Journal of Health Policy, vol.85, no.3, p. 263-276.

Mert, I.S. (2011). Çalışanların Performans Değerlendirme Sisteminin Çıktı ve Engellerine Yönelik Algıları. Business and Economics Research Journal, vol.2, no.3, p. 87-108.

Mohamed Shaffril, H.A., Uli, J. (2010). The Influence Of Socio-Demographic Factors On Work Performance Among Employees Of Government Agriculture Agencies In Malaysia. The Journal of International Social Research, vol.3, no.10, p. 459-469.

Sabuncu, N., Gülseven, B., Karabacak, Ü. (1999). Yoğun Bakım Ünitelerinde Çalışan Hemşirelerin Stres Kaynaklarının Belirlenmesi. Yoğun Bakım Hemşireleri Dergisi, vol.3, no.1, p.10-14.

Sağlık Bakanlığı (2006). Sağlık Bakanlığına Bağlı Sağlık Kurum ve Kuruluşlarında Kaliteyi Geliştirme ve Performans Değerlendirme Yönergesi, T.C. Resmi Gazete, 26166, 12.05.2006.

Sağlık Bakanlığı (2007). Sağlıkta Performans Yönetimi, Performansa Dayalı Ek Ödeme Sistemi. Sağlık Bakanlığı Yayını, Ankara.

Tengilimoğu, D., Kocakoç, N. (2014). Sağlıkta Kalite ve Performans. Sağlık ve İnsan Dergisi, vol. 3, no.32 p. 12-19.

Tengilimoğlu, D., Toygar, Ş.A. (2013). Hastane Performansının Ölçümünde PATH Yöntemi. Sosyal Güvenlik Dergisi, vol.3, no.1, p. 50-78.

Türk Dil Kurumu, (2017). 24 Nisan 2017 tarihinde

http://www.tdk.gov.tr/index.php?option=com_gts\&arama=gts\&guid=TDK.GTS.58fd9f6c858358.79632406 adresinden erişilmiştir.

Xavier, J.V. (2015). A Study on the Effectiveness of Performance Appraisal System and Its Influence With The Socio-Demographic Factors of The Employees of a Manufacturing Industry in Tamil Nadu. International Journal of Research in Management \& Business Studies, vol.2, no.1, p. 26-31.

Yıldız, O., Dağdeviren, M., Çetinyokuş, T. (2008). İşgören Performansının Değerlendirilmesi İçin Bir Karar Destek Sistemi Ve Uygulaması. Gazi Üniversitesi Mühendislik ve Mimarlık Fakültesi Dergisi, vol.23, no.1, p. 239-248. 